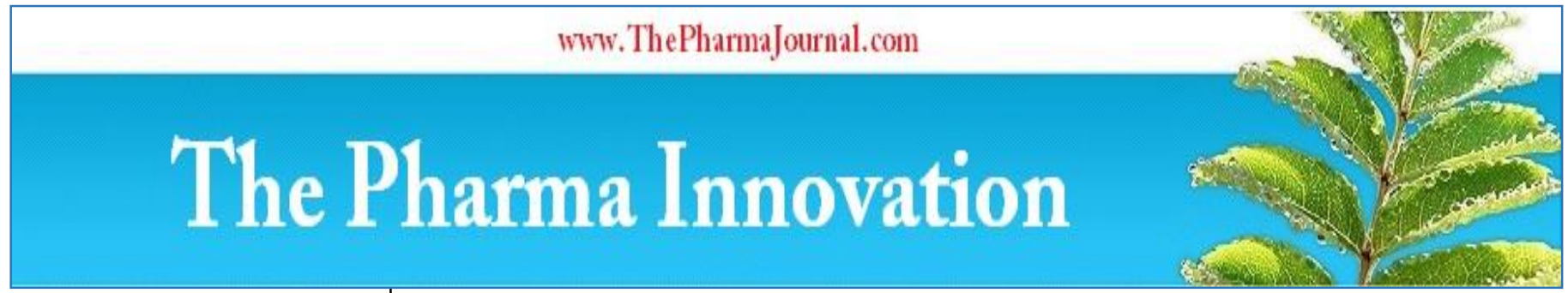

ISSN (E): 2277 - 7695

ISSN (P): 2349-8242

NAAS Rating: 5.23

TPI 2021; SP-10(5): 117-121

(C) $2021 \mathrm{TPI}$

www.thepharmajournal.com

Received: 15-03-2021

Accepted: 24-04-2021

Smruti Rekha Panigrahi

Department of Family Resource

Management, Collage of

Community Science, Assam

Agricultural University, Jorhat,

Assam, India

Dr. Ruplekha Borah

Professor, Dean, Collage of

Community Science, Assam

Agricultural University, Jorhat,

Assam, India

Dr. Bijoylaxmi Bhuyan

Assistance Professor

Department of Family Resource

Management, Collage of

Community Science, Assam

Agricultural University, Jorhat,

Assam, India
Corresponding Author:

Smruti Rekha Panigrahi

Department of Family Resource

Management, Collage of

Community Science, Assam

Agricultural University, Jorhat,

Assam, India

\section{Posture analysis of women involved in papad making process in Ganjam district of Odisha}

\author{
Smruti Rekha Panigrahi, Dr. Ruplekha Borah and Dr. Bijoylaxmi \\ Bhuyan
}

DOI: https://doi.org/10.22271/tpi.2021.v10.i5Sb.6186

\begin{abstract}
Papad making activity consists of repetitive actions and long hours of working in awkward posture which may lead to Musculoskeletal disorder in the long run. An attempt was therefore made to evaluate the posture assumed by workers in selected activities of papad making process. The postures assumed in selected sub-activities were assessed by using RULA, OWAS and flexi curve. From the survey it was found that women carried out papad making activity in a daily basis for 4-5 hours/day. The process of papad making requires a combination of postures like sitting, squatting, bending, and standing. Most of the sub activities were done in sitting-cum forward bending postures. Repetitive movements were found in upper limbs whereas static postures were maintained by lower limbs. RULA method was used to assess the postures assumed by upper limbs and lower limbs in ball making and rolling sub-activities of papad making. A RULA score of ' 5 ' in ball making indicated 'to investigate further and changes are required soon', where as in rolling process a score of ' 7 ' indicated 'investigation and change immediately'. OWAS posture analysis was carried out in sun drying activity for two sub activities of picking papads and carrying papads both scored ' 2 ' which fell under $2^{\text {nd }}$ action category that indicated "Light stress and no immediate action is necessary, but changes should be considered in future." Therefore, ergonomic intervention is required to lower the risk of musculoskeletal disorder among the workers by improving the working postures with the help of workplace modification and using advanced tools.
\end{abstract}

Keywords: Work posture, RULA, OWAS, musculoskeletal disorder

\section{Introduction}

Papad making was a common practice and had become a petty business prevalent either at household level, or at cluster level in Ganjam district with a large involvement of female workers. There were very few larger units as well carrying out the business in bigger scale. Papad making - in general a part of cottage industry where some of the sub activities were still performed manually with simple tools such as rolling of papads in their own homes. Cases of WMSDs were more common in these work places as the workers had to spend long hours, maintaining awkward postures, while performing the activities of papad making. It is also regarded as one of the profit making businesses for the people. This prioritised the importance of ergonomics in these work places so as to reduce the risk of harm or injury among the workers, increasing their efficiency and ensuring their safety and sustain the opportunities for income generation of the households through the skill of papad making.

\section{Methods and Materials}

\section{Locale of the study}

The present study was carried out at Ganjam district, Berhampur city.

\section{Sampling procedure}

The sample for the present study was selected by following purposive cum proportionate allocation technique.

\section{Selection of district}

Ganjam district was selected purposively due to the ease of researcher in collecting data. As the study is on papad making, Ganjam district is famous for papad making activity.

\section{Selection of city}

Berhampur city was selected purposively. As this city is famous for its different variety of handmade papad. 


\section{Selection of sample}

Berhampur city was selected purposively for the study. A total number of 120 samples were selected for the study by probability proportionate to size method.

\section{Reference period}

Reference period from 2018-2020.

\section{Method of data collection}

For the study, interview cum observation method was used for collection of data. Data were collected personally by the researcher. All the respondents were interviewed on pre-tested structured schedule. Care was taken that only reliable and valid information were being noted down in the schedule. For posture analysis still photographs and video technique was used along with careful observation while performing different activities of papad making women.

\section{Results and Discussion}

In this section, it includes of the information about the background of the respondents, personal and family background information and profiles related information of the respondents, like age, education qualification, main occupation, types of family, size of family, monthly income.

Table 1: Distribution of respondents according to their personal and demographic profile

\begin{tabular}{|c|c|c|c|}
\hline Sl. No. & Particulars & Frequency (f) & Percentage $(\%)$ \\
\hline 1. & \multicolumn{3}{|c|}{ Age of the respondents } \\
\hline & $18-25$ & 17 & 14.2 \\
\hline & $25-30$ & 31 & 25.8 \\
\hline & $30-40$ & 49 & 40.8 \\
\hline & $40-50$ & 21 & 17.5 \\
\hline & $>50$ & 2 & 1.7 \\
\hline 2. & \multicolumn{3}{|c|}{ Marital status } \\
\hline & Unmarried & 16 & 13.3 \\
\hline & Married & 88 & 73.3 \\
\hline & Widow & 16 & 13.3 \\
\hline 3. & \multicolumn{3}{|c|}{ Educational qualification } \\
\hline & Uneducated & 72 & 60.0 \\
\hline & Primary school & 29 & 24.2 \\
\hline & High school & 19 & 15.8 \\
\hline 4. & \multicolumn{3}{|c|}{ Main occupation } \\
\hline & Unemployed & 40 & 33.3 \\
\hline & Farming & 38 & 31.7 \\
\hline & Business & 22 & 18.3 \\
\hline & Service & 11 & 9.2 \\
\hline & Any other & 9 & 7.5 \\
\hline 5. & \multicolumn{3}{|c|}{ Family type } \\
\hline & Nuclear & 87 & 72.5 \\
\hline & Joint & 33 & 27.5 \\
\hline 6. & \multicolumn{3}{|c|}{ Family size } \\
\hline & 3-4 members & 88 & 88 \\
\hline & 5-8 members & 32 & 32 \\
\hline 7. & \multicolumn{3}{|c|}{ Income per month } \\
\hline & $<3000$ & 8 & 6.7 \\
\hline & $3000-5000$ & 105 & 87.5 \\
\hline & $>6000$ & 7 & 5.8 \\
\hline
\end{tabular}

Personal and demographic characteristics of the respondents

Age of the respondents

Age is a very important variable in ergonomic study as it affects the working capacity of an individual. Out of the total women selected for the present study, majority of respondents i.e. $40.8 \%$ belonged to the age group of 30-40 years, followed by 25.8 percent in the category of 23-30 years and only 1.7 percent belonged to the elder age group of $>50$ years (Table $1)$.

\section{Marital status}

Table 1 shows that 73.3 percent of respondents were found to be married followed by 13.3 percent unmarried and rest 13.3 percent were widows. Since the activity was performed at home, so the married women with the responsibilities of household work and children to look after could perform this activity with ease. The grown up children of these women sometimes extended help in performing the activities.

\section{Educational qualification}

According to the survey, it was revealed that majority (60 percent) of respondents were found to be uneducated without any formal education, followed by 24.2 percent studied up to primary school and rest only 15.8 percent were found to have high school education (Table 1).

\section{Main occupation}

Papad making was found to be the main occupation of the respondents according to (Table 1). Majority (33.3 percent) of the respondent managed their livelihood because of papad making business, 31.7 percent respondent depended on agriculture as their main source of income, followed by 18.3 percent on business and 9.2 percent depended on jobs as the main source of income and the rest ( 7.5 percent) were engaged in other occupation for the main source of income.

\section{Family type}

Nearly 72.5 percent of respondents had nuclear families and only 27.5 percent lived in joint family. The reason for 
majority of the families were nuclear was because many of the family members had migrated to other states for livelihood (Table 1).

\section{Size of the family}

It was revealed that, 73.3 percent respondents had family size of 3-4 members. Rest of the respondents, 26.7 percent belonged to a large size family consisting of 5-8 members.

\section{Monthly income}

The table reveals that the Monthly income of the respondents ranged from Rs.3000 to 6000. Respondents (87.5) percent earned wages between Rs.3000- 5000, followed by 6.7 percent of the respondents who earned wages up to Rs. 3000, and the rest of 5.8 percent of respondents had a monthly income of more than Rs. 6000. Respondents involved in multiple activities of papad making earn more than the respondents involved in a single activity. Newly engaged respondents were paid less than experienced ones. They were also evaluated in terms of rate of work doing work and with perfection (Table 1).

Extent of involvement of women in papad making activity Extent of involvement can be defined as women's participation in papad making activity in terms of 'daily', 'weekly', 'monthly'. It was observed that cent percent of women carried out papad making activity daily.

Table 2: Distribution of respondents of different age groups according to years of involvement $(n=120)$

\begin{tabular}{|c|c|c|c|c|c|}
\hline $\begin{array}{c}\text { Age } \\
\text { group }\end{array}$ & $\begin{array}{c}\mathbf{1 - 5} \\
\text { years }\end{array}$ & $\begin{array}{c}\mathbf{6 - 1 0} \\
\text { years }\end{array}$ & $\begin{array}{c}\mathbf{1 1 - 1 5} \\
\text { years }\end{array}$ & $\begin{array}{c}\mathbf{1 6 - 2 0} \\
\text { years }\end{array}$ & $\begin{array}{c}\mathbf{2 1 - 2 5} \\
\text { years }\end{array}$ \\
\hline $18-25$ & 15 & 1 & 1 & - & - \\
\hline$(\mathrm{n}=17)$ & $(12.5)$ & $(0.8)$ & $(0.8)$ & & \\
\hline $25-30$ & 16 & 11 & 3 & - & 1 \\
\hline$(\mathrm{n}=31)$ & $(13.3)$ & $(9.2)$ & $(2.5)$ & & $(0.8)$ \\
\hline $30-40$ & 19 & 24 & 6 & - & - \\
\hline$(\mathrm{n}=49)$ & $(15.8)$ & $(20.0)$ & $(5.0)$ & & 1 \\
\hline $40-50$ & 2 & 8 & 9 & 1 & $(0.8)$ \\
\hline$(\mathrm{n}=21)$ & $(1.7)$ & $(6.7)$ & $(7.5)$ & - & 1 \\
\hline$>50$ & 1 & - & - & & \\
\hline$(\mathrm{n}=2)$ & $(0.8)$ & & & & $(0.8)$ \\
\hline
\end{tabular}

\section{Years of involvement}

Table 2 revealed that, 44.1 percent of respondents were found to be working in the papad making industry for 1-5 years, followed by 36.7 percent respondents for 6-10 years, 15.8 percent respondents for 11-15 years and 2.5 percent for $21-25$ years. It was also found that the maximum number of 20 percent of respondents between the age group 30-40 years has worked for 16-20 years in the papad making industry.

Table 3: Job description

\begin{tabular}{|c|c|c|}
\hline Kind of work & Frequency (f) & Percentage (\%) \\
\hline Ball preparation & 20 & 16.7 \\
\hline Rolling & 55 & 45.8 \\
\hline Packaging & 1 & .8 \\
\hline All the above & 44 & 36.7 \\
\hline \multicolumn{3}{|c|}{ Duration of work } \\
\hline $8 \mathrm{am}-12 \mathrm{pm}$ & 9 & 7.5 \\
\hline 9am-1pm & 11 & 9.2 \\
\hline $10 \mathrm{am}-2 \mathrm{pm}$ & 84 & 70.0 \\
\hline $11 \mathrm{am}-3 \mathrm{pm}$ & 16 & 13.3 \\
\hline \multicolumn{3}{|c|}{ Time required for ball preparation out of $1 \mathrm{~kg}$ dough } \\
\hline $10 \mathrm{~min}$ & 68 & 56.7 \\
\hline $10-15 \mathrm{~min}$ & 38 & 31.7 \\
\hline $15-20 \mathrm{~min}$ & 14 & 11.7 \\
\hline \multicolumn{3}{|c|}{ Time required for rolling out of $1 \mathrm{~kg}$ dough } \\
\hline $10 \mathrm{~min}$ & 1 & 0.8 \\
\hline $10-15 \mathrm{~min}$ & 52 & 43.3 \\
\hline $15-20 \mathrm{~min}$ & 67 & 55.8 \\
\hline \multicolumn{3}{|c|}{ Place of work } \\
\hline Inside the house & 22 & 18.3 \\
\hline At roof top & 98 & 81.7 \\
\hline
\end{tabular}

Papad making is divided into different sub-activities i.e., dough making, ball preparation, rolling, drying, and packaging. Dough making was done with the help of machine and other steps were carried out manually. From data (Table 3 ), it was clear that majority of 45.8 percent of respondents were engaged in the rolling activity, followed by 36.7 percent were involved in all the four activities, 16.7 percent were involved in the ball making process and the rest 0.8 percent were involved in packaging activity. According to them rolling was the most time consuming activity so most of the respondents were involved to speed up the process.

\section{Duration of work}

Women were found to be multitasking, they had to complete their daily household activities (like: cooking, washing clothes, child care etc.) before starting papad making activity, this is the reason why respondents start their work in different time. It was found that $70 \%$ of respondents worked from 10 am - 2 pm, followed by 13.3 percent respondents from 11 am - $3 \mathrm{pm}$, and 9.2 percent respondents from $9 \mathrm{am}-1 \mathrm{pm}$ and rest 7.5 percent respondents worked for about $4 \mathrm{hr}$ i.e. 8 am - 12 pm.

\section{Amount of dough preparation per day}

Amount of dough making depends on the type of weather and season, during summer season they prepared the maximum amount of dough as compared to winter and rainy season if the weather outside is cloudy, amount of dough preparation decreases. It was found out that an approximate amount of 25$30 \mathrm{~kg}$ dough was prepared per day. 


\section{Time required for ball preparation out of $1 \mathrm{~kg}$ dough}

According to Table 3, 56.7 percent of workers spent 10 minutes to prepare balls out of $1 \mathrm{~kg}$ dough, followed by 31.7 percent of respondents took 10-15 minutes for ball preparation, and only 11.7 percent of respondents required 1520 minutes for ball preparation.

\section{Time required for rolling out of $1 \mathrm{~kg}$ dough}

According to Table 3, to roll out $1 \mathrm{~kg}$ dough 55.8 percent of workers required 15-20 minutes, followed by 43.3 percent who took 10-15 minutes and only 0.8 percent of respondents required 10 minutes for rolling.

\section{Place of work}

During the survey it was found out that (Table 3) dough making, ball preparation, and packaging were carried out inside the house. The other two processes of rolling and drying were carried out at the rooftop by 81.7 percent and the rest 18.3 percent of respondents worked inside the house.

\section{Rest period of the respondents}

Analysis of data in Fig. 1 revealed that, 56.7 percent of respondents used to take rest for about 10-15 minutes in between different activities, followed by 31.7 percent for 15 30 minutes and 11.7 percent of respondents had a rest period for 30 minutes and above. Majority of respondents who took rest for less time opined that resting for more time will affect their household activity. Respondents resting for 30 minutes belonged to older age group. According to them, since continuous sitting posture was adopted for most of the tasks which was tiring and involved forceful movement for which they required more rest period.

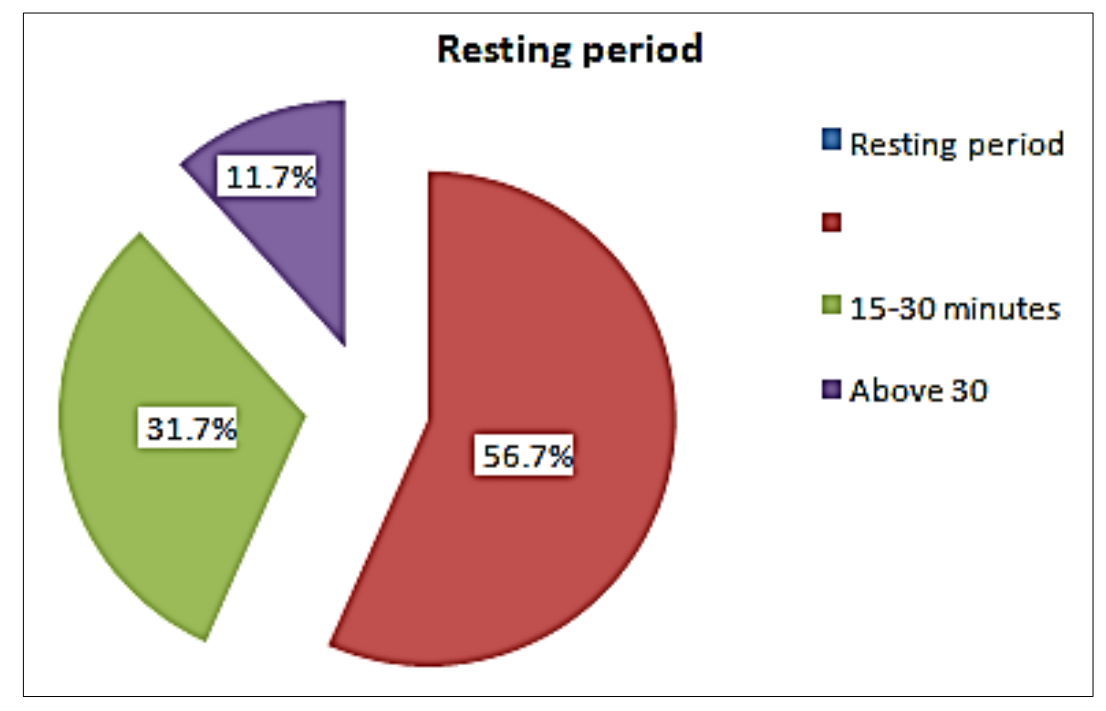

Fig 1: Rest period of the respondent

Posture assumed by respondents in papad making activity Posture is the position which holds our body upright against gravity. For maintenance of posture strong muscles of the body act to support the body against gravity. Due to poor posture, these muscles get weak, which produces increased strain on the supporting structures which may cause changes in the posture and long term muscular-skeletal deformities (Mane et al., 2018). The activity of Papad making was analysed by subdividing this activity into subtasks. Evaluation was done by using flexi curve and following standard protocols of RULA and OWAS. Assessment of postures of women involved in the sub tasks such as ball making, rolling and drying activities were studied by observation of still photography using RULA and OWAS scales. Neutral posture is maintained by a position of ease to the body for a longer period of time that supports the natural curves of the spine and maintain the body in good alignment. The position to sustain minimal effort and give biomechanical advantage to do work where the stress on the musculoskeletal system is reduced.
Table 4: Based on RULA analysis

\begin{tabular}{|c|c|}
\hline Subtask of papad making & RULA score \\
\hline Ball making & 5 \\
\hline Rolling & 7 \\
\hline
\end{tabular}

Remark: As the upper extremities are used therefore RULA is performed.

Table 4 shows that the grand score for RULA for the workers involved in ball making activity and rolling activity were ' 5 ', \& ' 7', respectively. RULA score for ball making activity ' 5 ' indicated that further investigation and changes are required soon. Whereas RULA score for rolling activity ' 7 ' indicated that investigation and changes are required now.

After keen observation of the sun drying activity and understanding the postural assumption through OWAS analysis, it was concluded that two sub activities of picking papads and carrying papads scored 2 and indicated that it was of "Light stress and no immediate action is necessary but changes should be considered in future". Further two other sub activities of carrying papads and walking for collecting papads scored 1 and indicated that "No actions are needed to change work postures" (Table 5). 
Table 5: Based on owas analysis of papad making activity - (sub activities of sun drying)

\begin{tabular}{|c|c|c|c|c|}
\hline \begin{tabular}{|c|}
$\begin{array}{c}\text { Sub activity of sun } \\
\text { drying }\end{array}$ \\
\end{tabular} & Diagrams & Code & Score & Action category \\
\hline Picking papads & & 2121 & 2 & \multirow{3}{*}{$\begin{array}{l}\text { Work postures have some harmful effect on musculoskeletal system. } \\
\text { Light stress, no immediate action is necessary, but changes should be } \\
\text { considered in future. }\end{array}$} \\
\hline Bending & & & & \\
\hline $\begin{array}{c}\text { BACK } \\
\text { FLEXION }\end{array}$ & & & & \\
\hline Carrying papads & & 1171 & 1 & \multirow{2}{*}{$\begin{array}{c}\text { Work postures are considered usually with no particular harmful effect } \\
\text { on musculoskeletal system }\end{array}$} \\
\hline Standing & & & & \\
\hline ARMS FLEXION & & & & No actions are needed to change work postures \\
\hline $\begin{array}{l}\begin{array}{c}\text { Filling basket with } \\
\text { papads }\end{array} \\
\end{array}$ & & 2121 & 2 & \multirow{3}{*}{$\begin{array}{l}\text { Work postures have some harmful effect on musculoskeletal system. } \\
\text { Light stress, no immediate action is necessary, but changes should be } \\
\text { considered in future. }\end{array}$} \\
\hline Bending & & & & \\
\hline $\begin{array}{c}\text { ARMS } \\
\text { EXTENSION }\end{array}$ & & & & \\
\hline Walking & & 1271 & 1 & $\begin{array}{c}\text { Work postures are considered usually with no particular harmful effect } \\
\text { on musculoskeletal system }\end{array}$ \\
\hline Standing & & & & \multirow[b]{2}{*}{ No actions are needed to change work postures } \\
\hline Back Neutral & & & & \\
\hline
\end{tabular}

\section{Assessment of postural deviation with the help of flexi curve}

To assess the postural stress on women while working, the angle of deviation of the spine was measured.

Findings (Table 6) of the study highlighted that angle at the normal position of the spine was measured as 194 degrees whereas while performing ball making and papad rolling activities it deviated to 200.03 and 200.4 degrees respectively indicating an increase over the base as 7 and 6.17 degree respectively and the percent increase over the base was $3.06 \%$ and $3.17 \%$ respectively.

Table 6: Assessment of postural deviation of papad making activities performed by workers $(n=30)$

\begin{tabular}{|c|c|c|}
\hline & Ball making & Rolling \\
\hline Angle at normal position & $194 \pm 7.48$ & $194.23 \pm 6.08$ \\
\hline Angle at working position & $200.033 \pm 6.35$ & $200.4 \pm 5.32$ \\
\hline Increase over base & 7 & 6.17 \\
\hline Mean difference & 6.5 & 6.1 \\
\hline Percent increase & $3.06 \%$ & $3.17 \%$ \\
\hline
\end{tabular}

\section{Conclusion}

Women involved in papad making activity on daily basis were found to assume different awkward postures during different sub activities among which rolling activity was found as "very heavy" activity. It could be concluded that awkward postures for longer durations results in discomfort in different body parts and development of pain in lower neck, shoulders, back bottom, lower arm, wrist, hands and knees leads to musculoskeletal disorder among these women. Therefore, findings suggested that further studies in this area can bring contribution on these reducing musculoskeletal problems of the back and arms. Ergonomic intervention is thought to be necessary for the postural health of the workers.

\section{References}

1. Hoy D, Brooks P, Blyth F, Buchbinder R. The Epidemiology of Low Back Pain. Best Pract. Res. Clin. Rheumatol 2010;24(6):769-781.

2. Maity P, Sujaya D, Pal A, Mahata H, Chatterjee M,
Dhara PC. Identification of A Suitable Working Posture For Female Workers Engaged In Golden Thread Work. International Journal of Occupational Safety and Health 2014;4(2):24-33.

3. Raia A, Gandhib S, Sharma DK. Ergonomic Evaluation of Conventional and Improved Methods of Aonla Pricking With Women Workers. M.Sc. Thesis, CCS Haryana Agricultural University, Hisar, India 2012.

4. Osborne A, Blake C, Fullen BM, Meredith D, Phelan J, Namara J. Prevalence of Musculoskeletal Disorders among Farmers: A Systematic Review. American Journal of Industrial Medicine 2012;55:143-58.

5. Sarkar K, Dev S, Das T, Chakrabarty S, Gangopadhyay S. Examination of Postures and Frequency of Musculoskeletal Disorders Among Manual Workers In Calcutta. India Int. J Occup. Environ. Health 2016;22(2):151-158.

6. Montakarn C, Nuttika N. Physical Activity Levels and Prevalence of Low Back Pain in Thai Call-Center Operators. Indian J Occup. Environ. MedI 2016;20:125128.

7. Pal A, Dhara PC. Work Related Musculoskeletal Disorders and Postural Stress of The Women Cultivators Engaged In Uprooting Job of Rice Cultivation. Indian Journal of Occupational and Environmental Medicine 2018;22:163-169.

8. Borah S. Ergonomic Assessment of Drudgery of Women Worker Involved In Cashew Nut Processing Factory In Meghalaya, India 6th International Conference on Applied Human Factors and Ergonomics (AHFE 2015) and The Affiliated Conferences, AHFE 2015 Procedia Manufacturing 2015;3:4665-4672.

9. Singh D, Kaur J. Ergonomic Risk Factors in Women Workers Involved in Handicraft Industry of Patiala District: Volume IX: Aging, Gender And Work, Anthropometry. Ergonomics for Children And Educational Environments 2019. 10.1007/978-3-31996065-4_43. 